\title{
The Many Faces of Turku - An Essayistic Study of Urban Travel
}

\section{Matti Itkonen}

University of Jyväskylä, Finland

\section{Abstract}

What does it mean to take a photographic, imaginary, or fictional journey to some destination? How does indirect observation of the object differ from direct observation? What are they like, the immediate and the mediated Turku? Which of them is more real or more authentic? Turku is Finland's most poetic city. It is also the most European of our cities. As the flâneur saunters along the banks of the River Aura, he traverses several centuries. The murmur of yesteryear is to be heard in the old buildings and in the foliage of the timehonoured trees. Here is the cradle, the first home of Finnish civilization. The philosopher-poet is able to see into the essence of a city: he has the patience to linger and listen to the humming resonance of the ages. The tourist cannot do that. What is needed is a traveller who makes sufficiently profound and discerning observations. It is in his existential looking glass that the many faces of Turku are reflected.

Keywords: essaystic study, urban travel, flâneur, Turku-ness, cultural-pedagogical city tour

\section{Introduction}

\section{Prologue}

The flâneur stands in the lush Linnanpuisto (Castle Park) and stares spellbound at the seemingly ancient name plate. It's

the same as the one in Samppalinna. They are both redolent of the past, of a yesteryear that has long since gone. The flank of the castle gleams a brilliant white. Around it the old trees stretch out and upwards. The grass is awash with a summer greenness. There is a powerful scent of flowers. And above everything there stretches the deep blue firmament of the sky. It's the very height of summer.

This is Turku, city of poetry. You begin to sense its feel already on the train as you approach the station. The River Aura, flowing deep in its bed, cuts meanderingly through the landscape. It's as if it's incessantly whispering words of antiquity. It's precisely in this city where you can think of the poet V. A. Koskenniemi as a professor. 
Nowhere else. The writer Volter Kilpi also belongs here. And it was a good place for professor Sven Krohn to allow his philosophical ideas to develop and deepen.

People too seldom bother to take a walk round the castle. They go straight into the castle. The whole park area thus remains unseen and unexperienced. Yet, in this abundant greenery, in the soughing leafiness of these lofty trees, and in the tranquil retreats with their benches, it is possible to find quiet and restfulness. There is peace lying on the steps of the timber barns. The hustle and bustle of the city is far away. The noisy streams of tourists are gone. The mind rests. The proximity of the castle distances the traveller from the exhausting pace of everyday life. (See also Itkonen, 2019a, on flâneurism.)

\section{The magic circle of Turku}

"Is Turku a subject or an object?" I was recently asked. "A subject, of course," I answered without hesitation. Now I would give a more precise answer and say that Turku is both a subject and an object. This is something that merits more thorough examination.

Being a subject refers to action: a functioning and thinking being. Objectness, on the other hand, means being the object of an action or deed. So how then could a city actually appear in the role of a conscious and comprehending being? Of course, according to a strict interpretation, there is only one subject present in a situation, in a meeting between a person and a city. Yet the effect is undoubtedly two-way. There again, only one consciousness is involved in the creation of the Turku experience. Perhaps this is the point where even the phrase dialogic urban monologue could be used. Then the same person acts as questioner and respondent. One party in this totality, however, is the talk-inspiring appeal of Turku. Without Turku, there wouldn't be any dialogic urban monologue.

It's possible for a person to encounter different kinds of Turku. Or it's the same Turku all the time, but its essence, its urbanity, can be constructed in different ways. This is why we may be justified in talking about Turku's directness and its indirectness. Admittedly, the magical element probably implies that all of its manifestations feel like a firsthand Turku experience to the person experiencing them. So it is almost irrelevant whether you visit Turku in a very concrete way or through a photograph, a poem or a non-fiction text. Each time, the experience is almost as intense: the proof of this lies in the power of the dialogic urban monologue.

There's good reason to shed more light on this matter. Professor Rafael Koskimies's Porthan's Time (Porthanin aika) opens up a very interesting view of Turku. Typically of a research study, the description is objective and dispassionate: "Luostarinmäki, a designated museum area, provides an excellent and graphic insight into the lives of people living in the humbler areas of old Turku This part of the city, created in the closing years of the 18th century, ascends the slope of Vartiovuori as a uniform cluster of houses. The close proximity of the houses and their plots and the relatively regular 
'town plan' with its streets and alleys shows that this is really about an urban settlement and not a rural one. Its remoteness saved this treasure from the fire of 1827, and the Turku Historical Museum, by restoring the area's houses and homes wherever possible, has really kept this 150-year-old neighbourhood alive." (Koskimies, 1956, pp. 61-62)

The scientist's description is objective and dispassionate. It lacks ecstatic joy. The researcher's gaze is intent and thoughtful: itemizing, segmenting and seeking interpretation. Between the observer and the subject there is but a short distance. The researcher may think that he is located somewhere on the periphery of Turku's magic circle. The situation is similar in the official brochures and maps as well, where the object is also observed from some way off. In both cases, it seems as if the observer is looking at the world through spectacles of neutrality. There is no particular enthusiasm displayed. And there really is no need, because impartiality is a splendid starting point.

The tourist map of Turku is a good example of a matter-of-fact approach. The tone or spirit of the text is reminiscent of Koskimies's text: "An excellent overview of presentday Turku can be gained, for example, from the top of Vartiovuori, the site of one of C. L. Engel's early works, the observatory (nowadays a naval school), which was completed in 1818. However, the picturesque panorama that opens up is not particularly 'historic', since modern-day Turku, with its straight, wide streets and relatively modern houses, rose mainly out of the ashes of the great fire of 1827 (it destroyed $3 / 4$ of the city). However, charming Luostarinmäki (Cloister Hill) on the southern slope of Vartiovuori, with its interesting handicraft museum, has survived from before the time of the fire. The cathedral is still surrounded by the city of Turku's most uniform architectural centre, with its dominant neo-classical style." (Turku, 1950, pp. 3-4)

It can be assumed that, when depicted in a work of non-fiction and a map, Turku verges on appearing in the role of a pure object. Such descriptions lack ecstatic elation. And that's the way it should be. Otherwise, it wouldn't be possible to find a mode of presentation independent of one's own attitude. However, small details add a personal touch to both of the texts. Koskimies calls Luostarinmäki a treasure. The author of the map text has used the words "particularly" and "charming". I would argue that those traits also put Turku in the role of the subject. Nevertheless, the actual "dialogue" between the city and the person experiencing it is still missing. Perhaps one could argue that there is already the beginning of a small element of elation. This is something you need if you intend to reach into the core of the magic circle.

There is positive and negative elation. In this context, one should also be able to talk about the authenticity and inauthenticity of the manner in which elation comes about. The latter alternative involves excessive entanglement in media reality. Then the fundamentally important element becomes emphasising the presence of one's self. 
Turku as a whole has mere instrumental value in pursuing some ultimate goal. Perhaps it's also about arousing some kind of enchantment with Turku playing an essential role. In other words, the city then, at least partially, takes on the role of subject. It is, however, the person describing who has the main role, especially in constructing their own story in a suitable Turku environment.

An examination without examples lacks the necessary detail. I need a photograph and a poem to express the magic of Turku. I'll start with the photo.

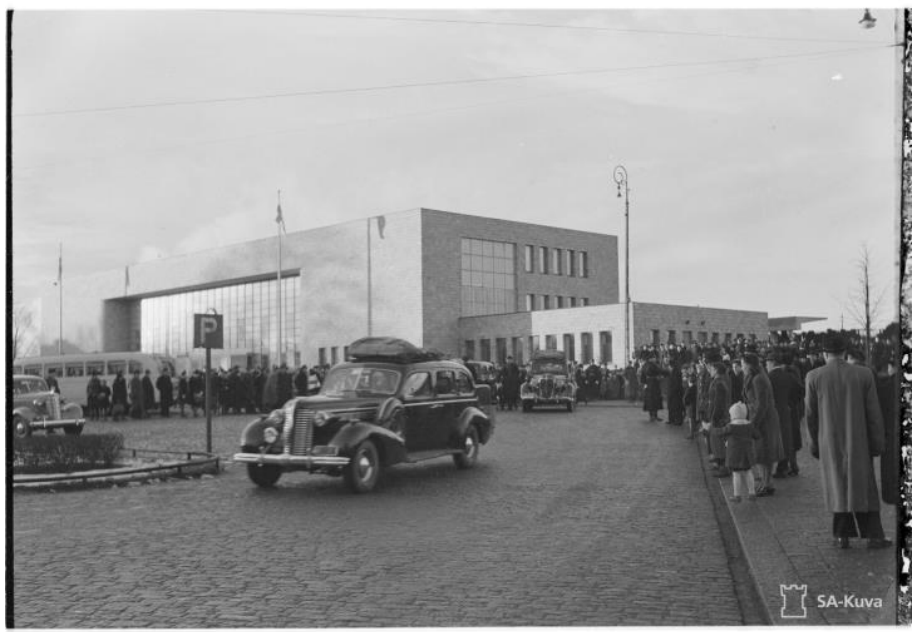

Photograph 1. Turku railway station.

More important than the photographer is the view of the place, the time and the people present. Here, the subjectivity of Turku, its Turku-ness, is consciously being constructed. Or you could think that Turku represents the whole of Finland and in its role as subject creates an entire domestic narrative.

The 'now' when the photograph was taken was the time of the Continuation War: the 1943 Independence Day celebrations. People were gathered at the railway station to receive President Risto Ryti. The Turku of yesteryear is also able to captivate the modern-day viewer. The place is of a time and yet it is also timeless. It's the people's clothing and the cars that actually tie it to the past. However, this view of the station itself is one you can still find. What it creates is a powerful impression of simultaneously being in the past and in the present. You could almost imagine yourself coming down to the station to check the train timetables.

In exceptional circumstances, positive stories are deliberately created. Still, I wouldn't make so bold as to argue that one possibility of elation linked to the image means inauthenticity. In fact, the complete opposite is true: the feeling of enchantment arises as if of itself. Turku in the role of subject gives the viewer the freedom to engage in an urban dialogue with Turku or to ignore the situation and continue their journey onwards. After all, this is precisely what travel advertising should be about. It's 
important that people retain a sense of free will. Let them decide what action to take in each case. For this reason, sophisticated leading is a better approach than intrusive imposition.

The anonymous observer wandering in the flow of Turku's city life is undoubtedly a concrete part of living Turku-ness. Their connection to the city's magic circle is immediate. Dialogic urban monologue is on-going throughout the entire walk. That is, it happens in a living situation. If a photograph is capable of transforming indirectness into at least a partial directness or immediacy, then a poem too can have a similar effect. It can bring elation to the reader and give Turku the role of a subject that speaks to the reader. This is also the mechanism by which profound travel essays are born.

This is appropriately illustrated by the poetry of V. A. Koskenniemi. The collection "Kurkiaura" (Wedge of cranes) includes the poem "Aboa vetus et nova". Initially, Koskenniemi wrote the poem for the cantata celebrating Turku's 700th anniversary (1929), i.e. for a fairly large composition. Nevertheless, even today, 90 years later, the poem still allows entry into Turku's magic circle. A brief extract says everything that matters.

"A full harvest has been brought

by the thoughts of your men:

at your school the rest of Finland

has learned the alphabet.

On your banks a great dream

was dreamt by young Arwidsson,

and the voice of Porthan

has resounded in your halls.

And once the power of your song

brought enchantment, splendour to your land:

when under the Ruissalo oaks

the harps of poetry echoed."

(Koskenniemi, 1930, p. 136.)

Of course, readers must have the courage and ability to immerse themselves in the enchanting fascination of the poem. Then the urban dialogue with the Turku-subject also becomes a reality. Likewise, the reader's soul is suffused with genuine and positive elation. Simultaneously the pathway to timeless Turku-rambles opens up. Likewise, this study is trying to offer such an opportunity for elation. We need more insightful, powerful and eloquent texts about the magic circle of Turku's Turku-ness. 


\section{Turku for travellers or tourists?}

Being and time are related to each other. Or maybe there would be more grounds for talking about time and being. The order depends on how the question of being is phrased: is time constructed from a specific being? Or does a certain time shape a specific being? In this essay being is the primary ingredient. Therefore, the specific order, being and time, is now the starting point for investigations. In other words, being begets time, Turku-time. It's part of Turku's more general time. Things will become clearer as the characterizations proceed.

Too often, the texts in travel magazines and the travel sections of newspapers are simply reports or some kind of case studies. They provide a summary of what happened. They are not travel descriptions or travel essays. Such writings lack both a literary dimension and any meditative depth. This fact is also seen in the disregard for linguistic correctness. Or then perhaps the writers simply don't know the rules of Finnish grammar. In particular, incorrect punctuation makes reading difficult. The text is full of the random commas familiar from a Peanuts comic strip. Yet it has nothing to do with creativity.

Does the flâneur belong in the traveller's Turku or the tourist's Turku? And does he wander in Turku-time or Turku's time? It is essential, therefore, to try and find out the nature of the flâneur's observations. However, an examination can't be made without documentation. Carrying out the investigation requires both visual and verbal "pieces of evidence". Indeed, the importance of the procedure has already become apparent in previous reflections. According to the principle outlined at the outset, first of all there has to be something before it can have some kind of temporal and local character. In this way, interpretations and stories are also created.

Once again, it is advisable to begin the investigation by analyzing two photographic documents.

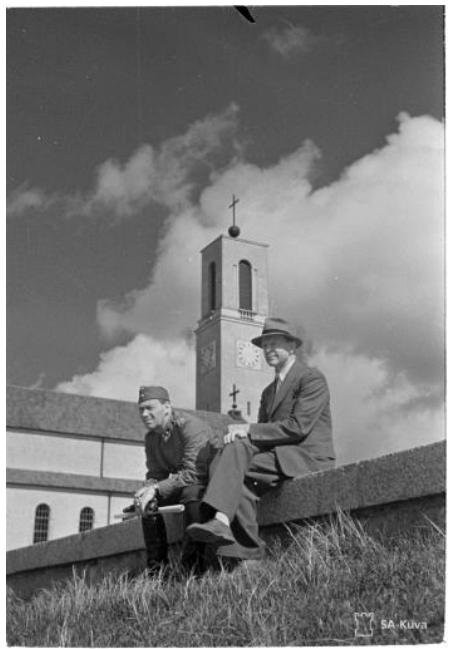

Photograph 2. The clock tower of the Martinkirkko. 


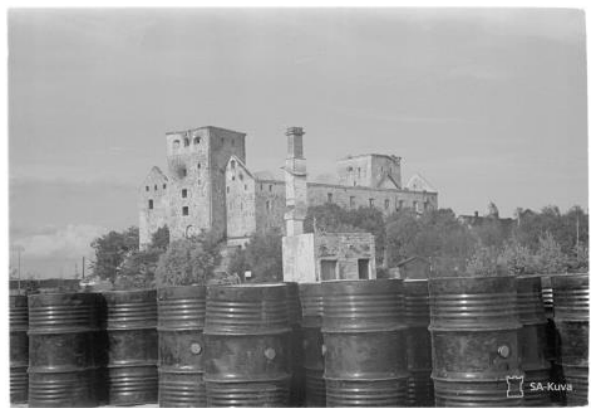

Photograph 3. The marks of war.

In photgraph two, we have reached the essence of Turku-time. This totality continues to include the question of possible differences between the traveller and the tourist. At that time the existential clocks of the church tower sometimes measured eternity. Their imaginary existential hands showed the essential instants of both humanity and culture. It's still possible to think of being able to hear time grow. I, too, am part of the landscape of time flowing through me. The war years of the early 1940s, the end of peace, three wars and the intellectual annihilation of Europe are suddenly within my grasp. The almost timeless atmosphere of the church milieu simultaneously connects me to the past, to the present and to an anticipation of the future. When the existential hands are aligned and overlapping, the presents of different times are suffused, passing through each other. For those arriving there was only one entire moment of Turku-time, its essence eternal. A tourist would always be bound by a mere dimensionless clock face. As a traveller I'm able to detach myself from the yoke of a mere clock face and look at the reality of Turku-time from inside.

There is something very symbolic in the fact that the Martinkirkko clocks have no hands. Is that moment of the Continuation War timeless, then? Perhaps the existential hands are aligned so closely on top of each other that the human eye cannot detect them. During the days of war, the soldier, the church tower with its crosses, and the sky with its white clouds represented important values for the nation They were probably marks of Finnishness and the will to survive. Therefore, it is quite justifiable to claim that picture two is part of both Turku-time and the Turku of the traveller. The camera is pointing upwards from below, which would seem to underline the importance of religion. It's as if the whole of being is reaching out toward heaven and God's sanctuary. The photo is uplifting in its spirit and mood. You can't relate the Turku of tourism to such insights. Only the outer shell is visible. (On the Martinkirkko, see, for example, Turun seurakunta, 2019.)

The tourist's time would thus be Turku's time. It would also mean time preshaped by an outside agent. It would only be left for the tourist to adhere strictly to the role ready written for him. You could think of finding a Turku like this in the descriptions of Mondo magazine, for example, and possible travel guides. A story of that sort can never do more than scratch the surface. Which is why the traveller goes his own way 
and exists in Turku-time. I wonder whether it would work if we called it interpretative Itkonen time? Or would it just be time for Itkonen to notice his excessive selfsatisfaction? I will answer these questions in my future research.

Photograph three shows Turku Castle after heavy damage by aerial bombing. The photographer was looking towards the castle from the harbour, which was where travellers generally departed and also arrived. In the rhythm of being this was a place encapsulating the essence of departure and return, or of beginning and ending. In this context the cycle of existence has both a concrete and symbolic significance. Sometimes peace foreshadows war and war foretells peace. Sadness is followed by joy, and a smile contains an imminent tear. Alternation is part of life. Yet, within this existential alternation a landscape destroyed by war represents ultimate despair. Ruins dominate the milieu. The roofless castle and the solitary chimney seem to be uttering an anguished request: "Stop the destroying, the rendering of everything into nothing."

Turku Castle resembles a temporal-cultural existential link, through which stories about Turku-time have been passed on for several centuries. They reveal a burning fire of civilization supported by nationalist respect. This idea, given an architectural form, has proudly carried the notion of Finnishness towards new futures. It's as if the arrangement of barrels in the foreground would like to tell you about the power of fire. Flames have destroyed the centuries-old signs of existence, even of Turku Castle. (On Turku Castle, see for example Museot, 2019.) It is at this point that our explorations should reach into Turku-time. To help describe this, I'll put together a brief practical example.

Kersti Bergroth, using the nom de plume TET, gives an interesting description of Turku in her book Suurin hulluus auringon alla (The Greatest Madness Under the Sun) (1928). Even today, the essence of the text lies in the perspective on the layered nature of being: "Turku is not easy to define right now. The old Turku is beginning to disappear from our consciousness, the new Turku is, at least in the eyes of the rest of Finland, the city of both [Finnish and Swedish] universities. And so far, the universities are still slightly theoretical concepts, still lacking the flesh and blood that tradition alone can provide. But actually, by cleverly connecting with what existed long, long ago, university life in Turku can very soon create its own convincing distinctiveness." (TET, 1928, pp. 112-113.)

What might war travel look like in Turku-time? One approach might be a culturalpedagogical city tour. For example, one suitable theme would be the various bombings of Turku. Then, with the aid of photographs two and three, you would be able to visit the places bombed during the war. What did the landscape look like then and what does it look like now? In school, this would work as a topic for a cultural week, for example, with the focus specifically on local studies. At the same time, it would offer an opportunity for cross-curricular integration. History, visual arts, 
philosophy as well as mother tongue and literature would open up interesting perspectives on layered Turku-time.

Another excellent travel companion would certainly be the newspaper Turun Sanomat. What did it report about the bombings of the city? Then you would quite concretely visit the places depicted in the texts. Photographs two and three would also fit in with this outline. It would be a multilevel cultural journey, where lived time blends with media reality time. A happier topic than war, though, would be cultural travel, and Bergroth's text would help in this. What must have happened over the decades for universities to change from theoretical concepts into highly respected seats of learning? Special college walks could be organized, which would reveal why it is easy nowadays to define Turku as a city of culture. In other words, university life in Turku would have created its own impressive distinctiveness, as already mentioned by Bergroth.

And is there also a Turku of memories and longing? Yes there is, and at the same time it is also a much loved city of schools. Just recently, I reread Aarne Mustasalo's novel Jokikylän abiturientit (The Graduates of Jokikylä), published in 1929. The author's real name was Heikki Nurmio. He had a master's degree and was also a jaeger officer. The novel contains some autobiographical features, for example, concerning Turku's Finnish realgymnasium. The eloquent cover picture is by Martta Wendelin. In places the language of the novel is beautiful and even touching. (On Mustasalo, see, for example, Raisio-Seura, 2019.)

The graduates of Jokikylä (river village) have very warm feelings for their school town. In particular, the final year of school and the approaching student examination bring emotions to the surface. In the centre of Turku, the graduates, well aware of their own worth, are only too willing to display themselves: "After returning from the school opening ceremony, we quickly ate dinner and headed to Linnankatu. We stopped at the corner of Aurakatu and gazed open-eyed on world history. Leaning on our rosewood canes, we took up a prominent position overlooking the centre of Turku and allowed people to admire ourselves." (Mustasalo, 1929, p. 15.)

The Jokikylä graduates also stand on Vartiovuori and deliver a rousing song to Turku: "Listen now, you doddery old man of Turku, our careful educator. Now your sons are singing a song for you - you, our famous, reknowned school town. Look at us up here. To you we sing, to you who has been the heart of Finland, the erstwhile cradle of light and freedom" (Ibid., 67.)

The novel gives a heart-stirring description of the sunrise of Turku and youth: "The sun rose and its golden rays first lit up the entire height of the cathedral tower, then the mountain ridges, roofs, gables and finally the whole city of Aura, hidden amongst its parks. Then, sparkling and flickering the day's sunbeams dart along the River Aura towards the castle and the sea." (Ibid., 214.) 
With the help of Mustasalo's novel you could also take a summery poetry trip to Turku. Then the Turku-time traveller could stand in front of Porthan's statue. At the same time, you would feel you were part of Finnish cultural history. The flowers would blaze with colour, and beneath the leafy expanse of the trees you would feel the soft breath of this old city of culture and education. It would be worthwhile for each and every person to travel to Turku and stay there for several days. There is so much to see and admire there. Given its historic background, the Scandic Plaza might be a suitably philosophical hotel for you to undertake in-depth city explorations. The Jokikylän graduates' farewell to their beautiful school town would also be suitable for a traveller bidding farewell to magical Turku: "There the cathedral rose up, a magnificent statue of eternity set against the sky, at whose base we had lived, worked, and rushed from adventure to adventure. Countless times we had seen its handsome pointed tower and cross, sometimes against a backdrop of threatening thunderclouds with their lightning flashes or dangling strands predicting winter snowstorms, sometimes against a calm and clear starlit spring sky, wondrously shimmering. It has been drawn definitively in the depths of our hearts, and every time its warmlycoloured form once again meets our eyes, we are overcome with a devout spirit of celebration, in our ears a melody stirs from former times, times of happiness and youth, of song and poetry, times which will not return. There is nothing to match it in Finland. ... That spring evening we sat quietly around the statue of Porthan, and our young chests radiated our warm gratitude to you, our exalted, gentle mother, beautiful old Turku." (Ibid., 210 and 211.)

Should I choose, in accordance with the title, a traveller's Turku or a tourist's Turku? The answer really depends on what the visitor expects or wants from their visit. Maybe both types of Turku are needed. However, if you have to choose, the traveller's Turku is definitely the right choice. This will open up the way to the world's Turku, which there again means seeing through the outer shell, into the heart of the city. Then, instead of the merely superficial, the historical-cultural essence comes to life. The Turku-wind blows from afar, from the very roots of Finnish civilization. The soughing centuries in Turku-time.

The traveller's Turku is a city of many layers. The tourist's Turku, on the other hand, is a city of consumption containing no more than a meagre moment of the present. Once you have taken a quick glance at it, you can move on and forget about the whole of Turku. It's just a city you have experienced. It also means a Turku of superficiality.

An experience remains in the mind for a long time. For this reason, Turku-time is a time of experience. Travellers are thrilled as they enter magical Turku. They become flâneurs who indulge in deep cultural insights. Thoughtful strolls through time and the city along the banks of the River Aura are the culmination of the Turku experience. And this is where essayistics starts. 


\section{Epilogue}

It's defintely a good idea to take a turn at the corner of Brahenkatu and acquaint yourself with the new library. Its brightness and brilliant whiteness are stunning. The flâneur was recently attracted to an exhibition in the lower lobby, which featured the winning gems of architectural competitions. The display wall dealing with Alvar Aalto and functionalism was particularly inspiring.

The library interior creates a sense of easy movement and unlimited space. The exterior space continues into the interior, which partly overlaps with the exterior. The surfaces are hidden or vanish somewhere into the distance. For the person experiencing this, it is easy to be a part of the whole, a living essential element of a constructed world. Granite stairs ascend towards the sky; at the top a clear bright glow is visible. It gives an extraordinarily strong impression of arriving at a destination and of warm-hearted closeness. The city of poetry has been given a worthy home for books. The elegant Artek store also blends well into this milieu. The traveller's mental journey ends in the close embrace of the cathedral bridge. (See also Itkonen, 2019b, on the spirit of place.)

English translation by Glyn Hughes

\section{References}

[1] Itkonen, M. (2019a). Eurooppa, Suomi ja ajan henki. Kulttuurimatkalla V. A. Koskenniemen kanssa. [Europe, Finland and the spirit of the age. On a cultural journey with V. A. Koskenniemi]. In: M. Itkonen, V. A. Heikkinen ja S. Inkinen, Maailman Turussa. Pohdinnallis-esseistisiä kulttuurikävelyjä Aurajoen rannoilla. Helsinki: Haaga-Helia ammattikorkeakoulu, pp. 19-76.

[2] Itkonen, M. (2019b). The Quintessential Kalastajatorppa. A Cinematic Journey into a Time and a Space. English translation by G. Hughes. Journal of Comparative Literature and Aesthetics 1 (42), pp. 118-129.

[3] Koskenniemi, V. A. (1930). Kurkiaura. Ballaadeja ynnä muita runoja. [A wedge of cranes. Ballads and other poems]. Porvoo: WSOY.

[4] Koskimies, R. (1956). Porthanin aika. Tutkielmia ja kuvauksia. [The age of Portan. Studies and depictions]. Helsinki: Otava.

[5] Museot. (2019). Turun linna. [Turku castle]. At: https://museot.fi/museohaku/?museo_id=21857. (Accessed 15.9.2019).

[6] Mustasalo, A. (1929). Jokikylän abiturientit. [The graduates of Jokikylä]. Gummerus: Jyväskylä.

[7] Raisio-Seura. (2019). Piirteitä Pernon kartanon ja sen omistajain historiasta. Jokikylän pojat. [Features of the history of the Perno estate and its owners. The boys of Jokikylä]. At: https://raisio-seura.fi/myyntiartikkelit/kirjat-jakortit. (Accessed 15.9.2019).

[8] TET. (1928). (K. Bergroth). Suurin hulluus auringon alla. [The greatest madness under the sun]. Helsinki: Kirja. 
[9] Turku. (1950). Matkailukartta. [Tourist map]. Turku: Turun kaupungin kiinteistö- ja rakennustoimiston mittausosasto.

[10] Turun seurakunta. (2019). Turun ja Kaarinan seurakunnat. Martinkirkko. [The parishes of Turku and Kaarina. Martin's church]. At: https://www.turunseurakunnat.fi/kirkot-ja-kappelit/martinkirkko. (Accessed 15.9.2019).

\section{Picture sources}

[11] SA-kuva-arkisto, Etulinjasta kotirintamalle 1939-1945. [SA picture archive. From the front line to the homefront 1939-1945]

[12] Photograph 1. Photographer Aavikko. At: http://sa-kuva.fi/.

[13] Photographs 2 and 3. Photographer E. Mäkinen. At: http://sa-kuva.fi 